TEME, г. XLIII, бр. 4, октобар - децембар 2019, стр. 1029-1044

Прегледни рад

https://doi.org/10.22190/TEME191014061D

Примљено: 15. 10. 2019.

UDK 343.9.02:343.1(497.11:4-672EU)

Ревидирана верзија: 14. 11. 2019.

Одобрено за штампу: 1. 12. 2019.

\title{
FORMING A GROUP FOR THE PURPOSE OF COMMITTING CRIMINAL OFFENCES \\ AS A CONTEMPORARY THREAT TO DEMOCRATIC \\ SOCIETIES - NEW CHALLENGES IN THE PROCESS \\ OF ACCESSION OF THE REPUBLIC OF SERBIA TO THE EUROPEAN UNION
}

\author{
Ivan Đokic ${ }^{1 *}$, Dragana Čvorović ${ }^{2}$ \\ ${ }^{1}$ Belgrade University, Faculty of Law, Belgrade, Serbia \\ ${ }^{2}$ University of Criminal Investigation and Police Studies, Belgrade, Serbia \\ *djokic@ius.bg.ac.rs
}

\begin{abstract}
The views of the contemporary criminal law doctrine have been emphasizing the importance of finding adequate criminal legal instruments of state response to organized crime for more than a decade, primarily bearing in mind the danger this form of crime poses to the contemporary, democratic society. The adequacy of the state response to organized crime requires a number of instruments that should be effective in the strategic field, in the field of ratified international documents, amended legal texts, which in the future would contribute to an even more effective fight in the field of detecting, proving and conducting proceedings for organized criminal offences. Taking into account the degree of danger of organized crime to modern society, including the criminal offence of forming a group for the purpose of committing crimes, it is necessary to react in all the fields mentioned above, especially with regard to the process of accession to the European Union.

The authors analyse the legal characteristics of the criminal offence of forming a group for the purpose of committing criminal offences, which is one of the basic types of criminalisation associated with organized crime. The authors also analyse the normative and practical measures that are a prerequisite for a more effective fight against organized crime and an important stepping stone on Serbia's path to the European Union.
\end{abstract}

Key words: $\quad$ organized crime, forming a group for the purpose of committing criminal offences, European Union, criminal charges, Prosecutor's Office for Organized crime. 


\title{
УДРУЖИВАЊЕ РАДИ ВРШЕЫА КРИВИЧНИХ ДЕЛА КАО САВРЕМЕНА ПРЕТЊА ДЕМОКРАТСКОМ ДРУШТВУ - НОВИ ИЗАЗОВИ У ПОСТУПКУ ПРИСТУПАЫА РЕПУБЛИКЕ СРБИЈЕ ЕВРОПСКОЈ УНИЈИ
}

\begin{abstract}
Апстракт
Ставови савремене доктрине више од једне деценије указују на значај проналажења адекватних кривичноправних инструмената државне реакције на организовани криминалитет, полазећи од опасности коју овај облик криминалитета представља за савремено, демократско друштво. Адекватност државне реакције на организовани криминалитет захтева велики број инструмената који би требало да делују на стратешком пољу, пољу ратификованих међународних докумената, измењених законских текстова, који би у перспективи допринели још ефикаснијој борби на пољу откривања, доказивања и спровођењу поступака за кривична дела организованог криминалитета. Узимајући у обзир степен опасности организованог криминалитета по савремено друштво, укључујући и кривично дело удруживања ради вршења кривичних дела, неопходно је реаговати на свим претходно поменутим пољима, посебно у процесу приступања Европској унији. Аутори у раду анализирају законска обележја кривичног дела удруживање ради вршења кривичних дела, које представља једну од основних инкриминација повезаних са организованим формама криминалитета, као и мере на нормативном и практичном плану које су услов за ефикаснију борбу против организованог криминалитета и важна претпоставка на европском путу Србије.
\end{abstract}

Кључне речи: организовани криминалитет, удруживање ради вршења кривичних дела, Европска унија, кривична пријава, Тужилаштво за организовани криминал.

\section{INTRODUCTORY REMARKS}

The criminalisation of the act of forming a group for the purpose of committing criminal offences protects both the public order and peace. The very alliance of certain persons to commit serious crimes is dangerous enough to require social reaction and criminalisation (Vuković, 2007, p. 179). Criminal legal protection here moves back, to the previous stage - the stage of preparing the delict. In this way, a significant preventive effect is also achieved, since it is possible to punish the organizer or a member of a particular group, regardless of whether the act involving the criminal plan around which the group was assembled has actually been executed (Vuković, 2007, pp. 179-180). At the same time, this act is also a typical offence in the field of organized crime, because, logically, almost every act that can be considered a part of organized crime stems from the previous offence of forming a group for the purpose of committing criminal offences, i.e. it is intrinsically linked to it (Škulić, 2015, p. 254). Despite its very limited use in practice, prescribing such a delict is a significant tool in the fight against organized crime. 


\section{LEGAL CHARACTERISTICS OF THE CRIMINAL OFFENCE OF FORMING A GROUP FOR THE PURPOSE OF COMMITTING CRIMINAL OFFENCES (ARTICLE 346 OF THE CRIMINAL CODE)}

The offence referred to in Article 346 of the Criminal Code has, in addition to its basic form, certain lighter and more serious forms.

The execution of the basic form (Criminal Code, 2005, Article 346, paragraph 1) consists of organizing a group aimed at committing criminal offences for which a sentence of imprisonment of three years or more severe punishment may be imposed, unless for such organizing a more severe punishment is provided for by the law. Organizing involves the creation of a new, hitherto non-existent form of association, or the use of an existing one that changes the basic function of action, or, in addition to the existing ones, the function of committing criminal offences as the basic one is added (Stojanović, Delić, 2017, p. 277). Organizing can be accomplished by various activities, such as recruiting other persons, creating a plan of action, gaining funds for the operation of a group, training members for committing criminal offences, and the like (Lazarević, 1995, p. 746). The exploitation of a preexisting form of criminal association basically implies giving new content to such an association, or substantially modifying it, so that it is transformed into a new organizational form having a criminal character (Škulić, 2015, p. 257). The organizer himself does not have to be a later member of the group. However, even a person who, at the time of the formation of the group, is an ordinary member and later acquires a decisive role in the pursuit of criminal goals cannot be considered an organizer (Vuković, 2007, p. 182).

A group is considered to consist of at least three persons connected for the purpose of perpetual or intermittent commission of criminal offences, and the group does not have to have defined member-roles, continuity of membership or a developed structure (Criminal Code, 2005, Article 112, Paragraph 22). The existence of a group requires certain organization of its members, but it does not require that they are more closely connected, nor does it require a higher degree of organization. Such an organization is, by the nature of things, necessary for the joint action of several persons, which amounts to the prior agreement of three or more persons to jointly commit crimes (Kraus, 1978, p. 773). Spatial cohesion of the group members is not necessary, so it is not a condition for criminal activity to be carried out exclusively in the territory of our country. Moreover, certain forms of organized crime imply the international character of a criminal organization (Vuković, 2007, p. 183-184). Whether the organizer will know all the members of the group or just some of them, as well as whether the members of the group will know each other or only some of them depends on the way the group is organized and the methods of action, and especially the degree of conspiracy that is sought (Kraus, 1981, p. 676). 
Organizing a group should aim at committing criminal offences. These offences are not closely defined, except that they are criminal offences for which a sentence of imprisonment of three years or more may be imposed. However, a certain type of criminal offence that the group will commit must be determined (Lazarević, 1995, p. 747). The commission of criminal offences may not be the sole aim of the group, but it must be the dominant, central activity of the group (Vuković, 2007, p. 185). In our literature, there are two different views regarding the legal nature of this characteristic relating to the gravity of the offence. On the one hand, this is an objective condition of criminalisation, i. e. a feature of a legal description of an act that does not have to be covered by the perpetrator's guilt. The second understanding starts from the view that it is a normative feature of the crime, which, in plain words, must be reflected in the perpetrator's consciousness (Vuković, 2007, p. 186-187).

An additional condition for the existence of this criminal offence is that the law does not provide for a more severe penalty for such organizing. This act is therefore of a subsidiary nature and will not exist unless the legislator has imposed a more severe penalty for similar activity (organizing), with additional conditions. For example, the legislator provides more severe penalties than the ones referred to in Article 346 of the Criminal Code for the creation of a group for the purpose of committing certain criminal offences against the constitutional order and the security of the Republic of Serbia because of the nature and gravity of those offences, so they would only be liable for such a severe offence.

The criminal offence is considered to be completed by the very creation of the group and it is not necessary that a specific crime is actually committed, for the purpose of which the group is organized. In the case of the commission of any of the planned acts, there will be a concurrence of criminal offences, association for the purpose of committing the criminal offences and the committed or attempted act. This view is undeniable in science and it is justified by the view that the group is organized for the purpose of committing an indefinite number of crimes and that it does not cease to exist by committing an individual crime (Atanacković, 1981, p. 542; Stojanović, 2017, p. 997). Previously, it was considered that the organizer was responsible not only for this crime, but also for any act that was committed in the implementation of the criminal plan of the association, even if they did not participate in it as a perpetrator, coperpetrator, abettor, or aider. This was made possible by certain provisions of the General Part. Namely, in our earlier criminal legislation there was a special case of complicity called organizing a criminal association. Under current rules, something like that is not possible. ${ }^{1}$

${ }^{1}$ According to the Article 26 of the Criminal Code of the FRY, as previously applicable, an organizer is a person who creates or exploits an organization, gang, 
Imprisonment between six months and five years is foreseen for the basic form of the criminal offence.

A more serious form of the crime is provided for in paragraph 2 and defined as committed by the organizer of the organized criminal group, unless the law provides for a more severe penalty for such organizing. Pursuant to Article 112, paragraph 35 of the $\mathrm{CC}$, an organized criminal group is a group of three or more persons, which exists for a certain period of time and acts by agreement with the purpose of committing one or more criminal offenses for which imprisonment of four years or more severe imprisonment is imposed, for direct or indirect gain of financial or other benefits. This form of crime is punishable by one to eight years in prison. Like the basic form, this more severe form will only exist unless a heavier penalty is prescribed for such organizing, so there is legal subsidiarity here as well.

Paragraphs 3 and 4 provide for less severe forms of the offense consisting of belonging to a group or an organized criminal group. Becoming a group member in this sense means accepting one's participation in achieving the goals of the group and expressing one's agreement to participate in the group. A member is an individual who is aware that he or she has become a member of the group and is willing to participate in the group's activities (Lazarević, 1995, p. 746). A member of the group will be sentenced to prison from three months to three years, whereas a member of an organized criminal group will be sentenced to prison from six months to five years. Belonging to a group, i.e. to an organized criminal group, involves actually joining it and acting in accordance with its interests and goals (Stojanović, Delić, 2017, p. 278). In this form, forming a group for the purpose of committing criminal offenses is a perpetual criminal offense accession to the association creates a continuous unlawful situation which the member willingly maintains or continuously prolongs with his or her actions (Vuković, 2007, p. 183). The literature points out that membership requires a longer period of time and a more lasting character of association with the group. One-off activities alone are not sufficient to establish the status of members, but continuous activity within the group is not necessary either. A member does not have to be the perpetrator or accomplice in every single act undertaken by other members of the criminal organization. It is also sufficient to carry out general, logistical tasks without the knowledge of particular planned acts - e.g. working on relations with other criminal groups or recruiting future members of the association (Vuković, 2007, p. 183). The offense is in itself done by the act of joining the group.

conspiracy, group or other association for the purpose of committing criminal offences. According to this provision, the organizer is punished for all criminal offences arising from the criminal plan of these associations as if he had committed them, regardless of whether he was directly involved in the execution of any of those acts (Srzentić, Stajić, Lazarević, 2000, p. 266). 
The qualified form of act (Criminal Code, article 346, paragraph 5) exists if the organization, i.e. membership, refers to a group or organized criminal group, which has the purpose of committing criminal offenses for which a sentence of twenty years' imprisonment or thirty to forty years' imprisonment may be imposed. ${ }^{2}$ The organizer of the group or organized criminal group shall be punished by imprisonment not less than ten years or imprisonment between thirty and forty years, whereas a member of the group or organized criminal group by imprisonment between six months and five years.

With regard to the subjective plan, all forms of acts imply the existence of intent. The perpetrator must be aware that he or she is organizing or belonging to an association that aims to commit crimes. The intent of the organizer, therefore, includes the awareness that he creates a group aimed at committing criminal offences, and with membership, that he has become a member of an association organized for the purpose of committing criminal offences (Lazarević, 1995, p. 747). The members of the group or the organizer do not need to be aware of the total number of members of the group or know each one in person (Vuković, 2007, p. 186).

For certain criminal political reasons, the legislator also provided for the privileged forms of this crime in paragraphs 6 and 7. The first milder form refers to the organizer. An organizer of a group or organized criminal group who, by uncovering a group or organized criminal group or otherwise prevent the commission of criminal offences for the purpose of which the group or organized criminal group is organized, shall be punished by imprisonment for a term not exceeding three years, and may be released from punishment. The uncovering of an association means informing the prosecution body of its participants (organizers and members) (Vukovic, 2007, p. 187). It is somewhat open to the question whether such repentant activity of the organizer is possible only before the group (organized criminal group) has already participated in the commission of one or more criminal offences, or if privilege is possible even after e.g. years of involvement in the group's criminal activities. Although this is not precisely specified in the legal text, certain methods of interpretation indicate that it is necessary that the detection or other prevention of the commission of criminal offences should be realized prior to the commission of any criminal offence (Vuković, 2007, p. 187).

Another milder form refers to a member of a group, or organized criminal group. A member of a group or organized criminal group who uncovers a group or organized criminal group before committing an

\footnotetext{
${ }^{2}$ The 2019 Criminal Code Amendment Act provides for life imprisonment instead of thirty to forty years imprisonment, so that the appropriate intervention was also made in the text of the offense under Article 346. These amendments enter into force on 1 December 2019
} 
offense as its member shall be punished by a fine or imprisonment for up to one year, and may be released from punishment.

The basis for privilege is the real remorse of the organizer or the group member. The criminal political significance of this provision is to stimulate the organizers and members of a criminal association to prevent the criminal organization from committing criminal offenses in a timely manner by reporting it to the competent state authorities. While it is sufficient for the organizer to disclose the association or otherwise prevent the execution of the act for the purpose of which the association was organized, a member of the group must not commit any of the acts covered by the group plan (Vuković, 2007, pp. 187-188).

\section{CRIMINAL LEGAL INSTRUMENTS OF STATE RESPONSE TO ORGANIZED CRIME AND THE CRIMINAL OFFENSE OF FORMING A GROUP FOR THE PURPOSE OF COMMITTING CRIMINAL OFFENSES - NEW CHALLENGES TO EU ACCESSION}

The Republic of Serbia faces serious challenges in terms of amending legal texts, drafting strategic documents, and taking a proactive approach to the fight against organized crime. Accordingly, Serbia has successfully responded to most of the requirements foreseen by the European Commission. Namely, a considering the degree of improvement of the normative framework of the Republic of Serbia, with regard to the previously presented documents, can best be seen through their analysis. In analyzing the issue at hand, particular attention will be paid to the recommendations made by the European Commission as primary in the Screening Report for negotiation chapter 23: Justice and Fundamental Rights, July 28, 2014. ${ }^{3}$

In response to the Screening Report for Negotiation Chapter 23 (Kolaković-Bojović, 2016), the Republic of Serbia, among other things, adopted: the National Judicial Reform Strategy 2013-2018, ${ }^{4}$ the Action Plan for the Implementation of the National Judicial Reform Strategy 2013-2018 and the Action Plan for Chapter $23,{ }^{5}$ adopted by the Government of the Republic of Serbia on April 27, 2016.

\footnotetext{
${ }^{3}$ Screening Report for Negotiation Chapter 23: Justice and Fundamental Rights, available at: http://seio.gov.rs/upload/documents/eu_dokumenta/Skrining/Screening\% 20Report\%2023_SR.pdf, accessed on July 19, 2019.

${ }^{4}$ The National Judicial Reform Strategy for 2013-2018 was adopted by the National Assembly of the Republic of Serbia on July 1, 2013, while the Government of the Republic of Serbia on August 31, 2013 adopted an Action Plan for the Implementation of the National Judicial Reform Strategy for the period 2013-2018.

${ }^{5}$ Action Plan for Chapter 23, available at: http://www.mpravde.gov.rs/files/Akcioni\% 20plan\%20PG\%2023.pdf, accessed on August 19, 2019.
} 
Taken from the aspect of the realization of the preventive and repressive aspects of organized crime criminal policy, we will analyse the legal framework of criminal legal response in the process of accession to the European Union. Namely, the Action Plan for Chapter 23 regulates the key areas that need to be changed through three segments: the judiciary area, the fight against corruption and fundamental rights. Each of these segments sets out recommendations, impact indicators and end results in the field of more successful criminal legal response to the fight against organized crime.

Within the judiciary and fundamental rights, there are procedural guarantees for a more effective fight against organized crime, which primarily include amendments to the Criminal Procedure Code (Criminal Procedure Code, 2011) (Bejatović, 2014; Škulić, 2014a), setting up an adequate monitoring mechanism for the implementation of the CPC and compliance with the CPC with European standards. Namely, the CPC (Škulić, 2014b), as a key instrument for combating organized crime, through the provisions on special evidentiary actions, special conditions for the examination of witnesses and experts, the temporal determinants of organized crime cases, greatly contributes to a more efficient fight, but also raises questions of adequate monitoring mechanism over the implementation of the CPC posed by the European Commission, especially in view of the changes that have occurred with the adoption of the new CPC, first of all by introducing a prosecutorial investigation and efficiency issues (Bejatović, 2015) of criminal procedure. According to recommendation No. 1.3.10 from the Action Plan, it is necessary to establish an adequate mechanism for monitoring the implementation of the CPC, which through the impact indicators and the results of the measures implemented, is determined through the commission for monitoring the implementation of the Criminal Procedure Code, which should report to the Commission regarding the implementation of the National Judicial Reform Strategy for the period 20132018 and receive a positive assessment by the European Commission on this issue. This particularly emphasizes the improvement of the efficiency of criminal proceedings in general, as well as criminal proceedings for organized crime offenses. Also, a very important segment of the improvement of the normative framework, but also of compliance with the European standards, is set through fundamental rights in the Action Plan, i.e. procedural guarantees (3.7.1.1. of the Action Plan), which, as a recommendation, provide for the reform of the defence provisions, the exercise of the right to a fair trial, but also to strengthen procedural guarantees, such as the presumption of innocence (3.7.10 of the Action Plan for chapter 23, 2016). Accordingly, among other things, it is necessary to pass a Law on Free Legal Aid (Čvorović, 2017), which was done, i.e. the realization of the fair process through equality of arms, which is an extremely important implication of the fair process in cases of organized crime. Also, 
compliance with European standards, the Directive 2013/48/EU, is necessary with regard to strengthening the right of access to a lawyer for suspects and defendants without delay and before any hearing by the investigating authorities in criminal proceedings.

In addition to the reform of the CPC, one of the significant instruments for achieving efficiency is the specialization of the organs for the detection and prosecution of organized crime offenses (Mijalković, Čvorović \& Turanjanin, 2019), including the criminal offense of forming a group for the purpose of committing criminal offences. This has been achieved by adopting the new Law on Organization and Jurisdiction of State Authorities in Suppression of Organized Crime, Terrorism and Corruption ${ }^{6}$ (Mijalković, Čvorović, 2018), hereinafter referred to as LOJSASOCTC. Namely, many of the recommendations in the Action Plan relate to securing independent, effective and specialized bodies (2.3.2. of the Action Plan for chapter 23, 2016) for prosecuting organized crime, corruption, strengthening independence measures, but also taking a proactive approach to improving cooperation and exchange of information between specialized bodies, better interconnection of databases, etc. Another recommendation (2.3.2.2. of the Action Plan for chapter 23, 2016) pertains to the amendment of the Law on Organization and Jurisdiction of State Authorities in Suppression of Organized Crime, Corruption and other Severe Criminal Offences, ${ }^{7}$ which was accepted by adopting a new legal text. In the new legal text (LOJSASOCTC) the recommendations from the Action Plan (2.3.2.4. of the Action Plan for chapter 23, 2016) were implemented by introducing a financial forensics service (LOJSASOCTC, 2016, Article 19), a liaison officer (LOJSASOCTC, 2016, Article 20) and forming task forces (LOJSASOCTC, 2016, Article 21).

In addition to the legal framework, a more effective fight against this form of crime is determined by the Strategic Framework, which in the process of accession to the European Union made a number of novelties. When it comes to organized crime, including the criminal offence of forming a group for the purpose of committing criminal offences, it is common knowledge that their actions are generating large profits and enormous financial power that affect all spheres of life, from the social to the political sphere, and that the seizure of the proceeds of crime should be one of the key instruments in the fight against organized crime within the strategic and legal framework. In this way, the organized criminal group

\footnotetext{
${ }^{6}$ Law on Organization and Jurisdiction of State Authorities in Suppression of Organized Crime, Terrorism and Corruption, 'Official Gazette of the RS', No. 94/2016.

${ }^{7}$ Law on Organization and Jurisdiction of State Authorities in Suppression of Organized Crime, Corruption and other Severe Criminal Offences, 'Official Gazette of the RS', No. 42/2002, 27/2003, 39/2003, 67/2003, 29/2004, 58/2004 - separate law, 45/2005, 61/2005, 72/2009, 72/2011- separate law, 101/2011- separate law and 32/ 2013.
} 
would gradually be destroyed and eventually disappear, thus achieving the international legal affirmation "that no one can become rich by committing crimes". Accordingly, the requirements of the European Commission to combat this form of crime more effectively have largely concerned the effective and permanent confiscation of property resulting from crime (2.3.5. of the Action Plan) and the improvement of the national framework. The European Commission has set as a primary requirement the adoption of the Law on Amendments to the Law on Seizure and Confiscation of Proceeds from Crime, in accordance with the previously conducted efficiency improvement analysis, based on EU Directive 2014/42 (2.3.5.1. of the Action Plan of the Action Plan for chapter 23, 2016). Accordingly, the Law on Amendments to the Law on Seizure and Confiscation of Proceeds of Crime was adopted (Law on Seizure and Confiscation of Proceeds of Crime, 2013). Also, the Financial Investigation Strategy for 2015-2016 was adopted (Financial Investigation Strategy for 2015-2016, 2015), as well as the National Strategy on Anti-Money Laundering and Combating the Financing of Terrorism (National Strategy on Anti-Money Laundering and Combating the Financing of Terrorism, 2008) and the National Strategy for Fight against Organized Crime (National Strategy for Fight against Organized Crime, 2009), etc.

In order to function in an adequate criminal policy of combating organized crime, the above reformed legal texts and the adopted Strategy must meet the contemporary requirements of combating this form of crime, it must be applicable, the organization and functioning of courts, prosecution and the police must be adequate, and the mutual cooperation of specialized bodies must be in accordance with the legal norm and with the aim of achieving the desired efficiency during pre-trial and criminal proceedings. The consideration of adequacy of the reformed framework of Serbia can best be seen through the practical application of the legal norm, i.e. the statistical indicators of criminal charges filed, criminal proceedings instituted and indictments filed by the Prosecutor for Organized Crime for the criminal offence of forming a group for the purpose of committing crimes and other organized criminal offences in 2019. 


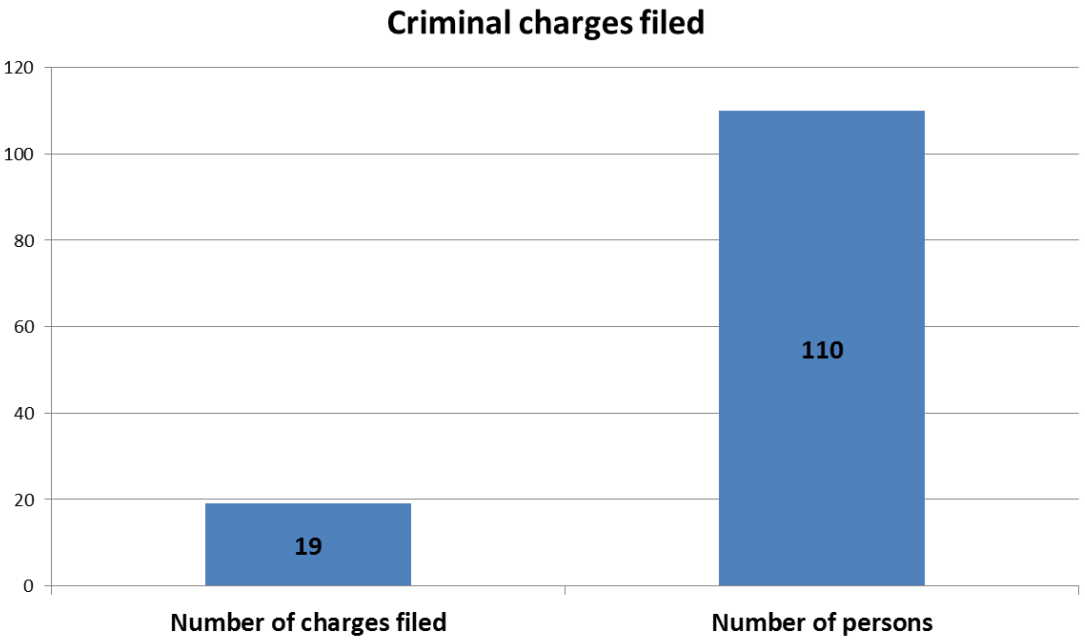

Diagram 1. Number of criminal charges filed in 2019 by the Prosecutor's Office for Organized Crime for the criminal offence of forming a group for the purpose of committing criminal offences compared to the number of persons against whom charges were filed

\title{
Number of investigations initiated and crimes for which they were initiated
}

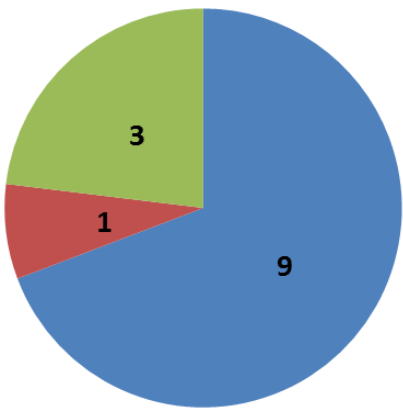

\author{
350 (4) of the CC of RS \\ 246 (4) of the CC of RS
}

346 of the CC of RS

Diagram 2. Ratio of criminal offences in 2019 initiated by the Prosecutor's Office for Organized Crime against a total of 62 persons 


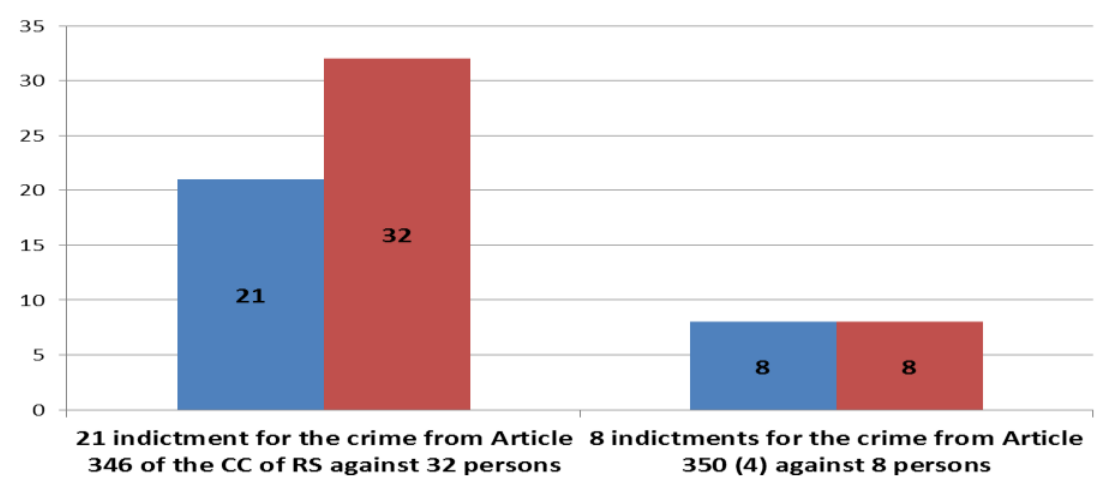

Diagram 3 Number of indictments filed in 2019 by the Prosecutor's Office for Organized Crime for criminal offences of forming a group for the purpose of criminal offences and illegal crossing of the state border and people smuggling

According to the statistic indicators for 2019 of the Prosecutor's Office for Organized Crime, 19 criminal charges were filed against 110 persons for the criminal offence of forming a group for the purpose of committing criminal offences. In total, 13 investigations were initiated against 62 persons, of which 9 investigations were initiated for the criminal offence of forming a group for the purpose of committing criminal offences alongside some other criminal offence from the Criminal Code of the Republic of Serbia; 1 investigation was initiated for the criminal offence of illicit production and marketing of narcotic drugs, but from paragraph 4 of the Criminal Code; and 3 investigations were initiated for the criminal offence of illegal crossing of the state border and people smuggling from paragraph 4 of the CC. As for the indictments, 21 indictments were filed against 32 persons for the criminal offence of forming a group for the purpose of committing criminal offences alongside some other criminal offence from the Criminal Code of the Republic of Serbia, whereas 8 indictments against 8 persons were filed for the criminal offence of illegal crossing of the state border and people smuggling from paragraph 4 of the Criminal Code of the Republic of Serbia.

The reformed normative framework, the specialization of state bodies for detecting, proving and prosecuting organized crime, including the criminal offence of forming a group for the purpose of committing criminal offences, represents a great step for Serbia in the process of accession to the European Union, but also the necessity to continue its work in order to create even more efficient normative foundations that will more adequately respond to contemporary challenges posed by organized crime. 


\section{CONCLUSION}

Although not often applied in practice, the crime of forming a group for the purpose of committing criminal offences is undoubtedly an important tool in the fight against organized forms of crime. It is almost impossible to imagine committing any organized criminal offence that would not be linked to this criminalization. The criminalization allows punishing not only the organizer of a group that aims to commit crimes of a certain gravity, but it also allows for the punishing of the membership to the group, regardless of whether or not one or more of the crimes for which the group was created was actually committed. This demonstrates the willingness of the state to act preventively in this area, threatening to punish a person for an essentially preparatory activity. In that sense, it can be said that there is full legitimacy for such criminalization, i.e. that from a criminal political point of view, it has been justifiably prescribed by the legislator.

The Republic of Serbia has made a significant effort to adapt its normative framework to European requirements on its path to the membership in the European Union. The newly introduced substantive and procedural mechanisms for combating organized crime undoubtedly show not only the willingness to persevere in the path of alignment with the European standards, but also to more successfully combat this form of crime.

\section{REFERENCES}

Atanacković, D. (1981). Krivično pravo. Posebni deo [Criminal law. Special Part], Beograd.

Bačić, F. (1978). Komentar Krivičnog zakona Socijalističke Federativne Republike Jugoslavije [Commentary of the Criminal Code of the Socialist Federal Republic of Yugoslavia], Beograd.

Bejatovic, S. (2014). Nekoliko razloga neophodnosti nastavka rada na reformi krivičnog procesnog zakonodavstva Srbije [Several reasons necessity of continuing work on the reform of criminal procedural legislation of Serbia]. In: Ilic, G. [ur.]: Reforma krivičnog prava [Reform of the criminal law]. Beograd: Udruženje javnih tužilaca i zamenika javnih tužilaca Srbije, 87-114.

Bejatovic, S. (2015). Efikasnost krivičnih postupaka kao međunarodni pravni standard i reforma krivičnog procesnog zakonodavstva Srbije [The efficiency of the criminal proceedings as an international legal standard and the reform of criminal procedural legislation of Serbia]. Revija za kriminologiju i krivično pravo, 3, $27-55$.

Cvorovic, D. (2017). Predistražni postupak i besplatna pravna pomoć [Pre-trial investigation phase and free legal aid]. In: Bejatovic, S\&Kolakovic- Bojovic, M. [ur.]: Besplatna pravna pomoć- ratio legis, obim i uslovi primene [Free Legal AidRatio legis, scope and condicions of application]. Beograd: Ministarstvo Pravde Srpsko udruženje za krivičnopravnu teoriju I praksu, 323-341.

Kraus, B. (1981). Komentar krivičnih zakona SR Srbije, SAP Kosova i SAP Vojvodine, Beograd [Commentary of the Criminal Codes of the FR Serbia, SAP Kosovo and SAP Vojvodina], Beograd. 
Kraus, B. (1978). Komentar Krivičnog zakona Socijalističke Federativne Republike Jugoslavije [Commentary of the Criminal Code of the Socialist Federal Republic of Yugoslavia], Beograd.

Kolakovic-Bojovic, M. (2016). Pristupni pregovori Republike Srbije sa EU u okviru poglavlja 23 i potreba za izmenom krivičnog procesnog zakonodavstva [Accession negotiations between the Republic of Serbia and the EU within the framework of chapter 23 and the necessity for amending criminal procedural legislation]. In: Ilic, G. [ur.]: Dominantni pravci razvoja krivičnog zakonodavstva i druga aktuelna pitanja u pravnom sistemu Srbije [Dominant directions of the development of criminal legislation and other current issues in the legal system of the Republic of Serbia]. Beograd: Udruženje tužilaca Srbije i Udruženje pravnika Srbije, 233-248.

Lazarević Lj. (1995). Krivično pravo Jugoslavije. Posebni deo [Criminal Law of Yugoslavia. Special Part], Beograd.

Mijalković, S., Čvorović, D. (2018). Migration, Terrorism and Possible Armed Conflicts in the Western Balkans, Security \& Future - International Scientific Journal, Scientific-Technical Union of Mechanical Engineering - Industry 4.0, Bulgaria, Year II, 3; ISSN Print 2535-0668, ISSN Online 2535-082X, chief editor: prof. dr Nikolay Radulov, 106-110.

Mijalković, S., Čvorović, D., Turanjanin, V. (2019). New Criminal Legal Challenges in Combating Organized Crime and Terrorism in the Republic of Serbia - A Big Step Forward. In Gjurovski, M. [ed.]: The Great Powers Influence on the Security of Small States. North Macedonia: University "St. Kliment Ohridski" - Bitola \& Faculty of Security - Skoplje, 87- 114.

Srzentić N, Stajić A, Lazarević LJ. (2000). Krivično pravo. Opšti deo [Criminal Law. General Part], Beograd.

Stojanović, Z. (2017). Komentar Krivičnog zakonika [Commentary of the Criminal Code], Beograd.

Stojanović Z, Delić N. (2017). Krivično pravo. Posebni deo [Criminal Law. Special Part], Beograd.

Škulić, M. (2015). Organizovani kriminalitet. Pojam, pojavni oblici, krivična dela i krivični postupak [Organized crime. Notion, forms, criminal offenses and criminal proceedings], Beograd: Službeni glasnik.

Skulic, M. (2014a). Pogrešna koncepcija i brojne pravno-tehničke greške novog Zakonika o krivičnom postupku - šta dalje i kako reformisati reformu srpskog krivičnog postupka [Misconception and numerous technical error of the new code of criminal procedure - What next and how to reform the Serbian reform process]. In Ilic, G. [ur.]: Reforma krivičnog prava [Reform of the criminal law]. Beograd: Udruženje javnih tužilaca i zamenika javnih tužilaca Srbije, 3-65.

Skulic, M. (2014b). Krivično procesno pravo [Criminal procedural law]. Beograd: Pravni fakultet.

Vuković, I. (2007). Krivično delo zločinačkog udruživanja i njegova obeležja: [član 346 Krivičnog zakonika] [Criminal Offence of Criminal Association and its characteristics: [art. 346. Criminal Code]. In: Nogo, S. [ur.]: Tematski međunarodni naučni skup Primena međunarodnog krivičnog prava organizovani kriminal, [Application of the international criminal law-organized crime], Tara: Udruženje za međunarodno krivično pravo, Intermex, 179-193. 


\title{
Legal Regulations and Other Acts
}

Akcioni plan za poglavlje 23, available at: http://www.mpravde.gov.rs/files/Akcioni\% 20plan\%20PG\%2023.pdf, accessed on August 19, 2019.

Krivični zakonik, „Službeni glasnik RS”, br. 85/2005, 88/2005, 107/2005, 72/2009, $111 / 2009,121 / 2012,104 / 2013,108 / 2014,94 / 2016$ i $35 / 2019$.

Zakonik o krivičnom postupku, „Službeni glasnik RS”, br. 72/11, 101/11, 121/12, 32/13, 55/14 i 35/2019.

Strategija istraga finansijskog kriminala za period od 2015. do 2016. godine, „Službeni glasnik RS”, br. 43/201516.

Zakon o oduzimanju imovine proistekle iz krivičnog dela, „Službeni glasnik RS”, br. 32/2013, 94/2016 i 35/2019.

Zakon o organizaciji i nadležnosti državnih organa u suzbijanju organizovanog kriminala, korupcije i drugih posebno teških krivičnih dela, „Službeni glasnik RS”, br. 42/2002, 27/2003, 39/2003, 67/2003, 29/2004, 58/2004 45/2005, 61/2005, 72/2009, 72/2011, 101/2011 i 32/ 2013.

Zakon o organizaciji i nadležnosti državnih organa u suzbijanju organizovanog kriminala, terorizma i korupcije, ,Službeni glasnik RS”, br. 94/2016.

Nacionalna strategija za borbu protiv pranja novca i finansiranja terorizma, „Službeni glasnik RS”, br. 89/08.

Nacionalna strategija za borbu protiv organizovanog kriminala, „Službeni glasnik RS”, br. $23 / 09$.

Izveštaj o skriningu za pregovaračko poglavlje 23: Pravosuđe i osnovna prava, available at: http://seio.gov.rs/upload/documents/eu_dokumenta/Skrining/Screening\%20Report \%2023_SR.pdf, accessed on August 19, 2019.

\section{УДРУЖИВАЊЕ РАДИ ВРШЕЊА КРИВИЧНИХ ДЕЛА КАО САВРЕМЕНА ПРЕТЊА ДЕМОКРАТСКОМ ДРУШТВУ - НОВИ ИЗАЗОВИ \\ У ПОСТУПКУ ПРИСТУПАЫА РЕПУБЛИКЕ СРБИЈЕ ЕВРОПСКОЈ УНИЈИ}

\author{
Иван Ђокић ${ }^{1}$, Драгана Чворовић ${ }^{2}$ \\ ${ }^{1}$ Универзитет у Београду, Правни факултет, Београд, Србија \\ ${ }^{2}$ Криминалистичко-полицијски универзитет, Београд, Србија
}

\section{Резиме}

Криминалитет уопште, а посебно његове организоване форме, које подразумевају учествовање у криминалној активности већег броја људи, уз мање или више изражену спрегу са структурама државне власти, представљају изузетну опасност по савремено друштво. Стога је изградња ефикасног механизма за супротстављање, како на нормативном тако и на практичном плану, од пресудног значаја у борби против организованог криминалитета. Република Србија је, барем када је реч о законодавној активности, предузела значајне кораке у настојању да адекватно одговори на претње организованих криминалних група по интересе поретка. Осим одговарајућих мера и инкриминација у Кривичном законику, предвиђени су и релевантни механизми у Законику о кривичном поступку, а нормативни оквир је обогаћен усва- 


\section{4}

јањем Закона о одузимању имовине проистекле из кривичног дела, као и Закона о организацији и надлежности државних органа у сузбијању организованог криминала, тероризма и корупције.

На свом путу ка чланству у Европској унији, а као одговор на Извештај о скринингу Европске комисије за преговарачко поглавље 23, Република Србија је, између осталог, донела: Националну Стратегију реформе правосуђа за период 20132018. год., Акциони план за спровођење Националне стратегије реформе правосуђа за период 2013-2018. год. и Акциони план за поглавље 23, који је Влада Републике Србије усвојила 27. априла 2016. год.

Анализирано кривично дело удруживања ради вршења кривичних дела, према ранијој терминологији, злочиначко удруживање, јесте незаобилазно дело у сфери организованог криминалитета, јер је готово незамисливо било какво организовано вршење кривичних дела, а да претходно нису остварена обележја ове инкриминације. Оно омогућава кажњавање лица које организује групу за вршење кривичних дела одређене тежине, независно од тога да ли је заиста и учињено неко кривично дело ради чијег вршења је удружење створено, тако да представља деликт препреку, које суштински кажњава једну припремну радњу. Осим организатора, казном затвора је запрећено и припадништво групи. Иако ово кривично дело није често у судској пракси (у 2018. години било је 19 осућујућих одлука), оно представља значајно средство у борби против организованог криминалитета.

Реформисани нормативни оквир, специјализација државних органа откривања, доказивања и вођења поступка за кривична дела организованог криминалитета, укључујући кривично дело удруживања ради вршења кривичних дела, представља велики корак за Србију у процесу приступања Европској унији, али исто тако и неопходан је и наставак рада, са циљем стварања још ефикасније нормативне основе која ће адекватније одговорити на савремене изазове које намеће организовани криминалитет. 